\title{
Students' Civil Identity Formation in Multicultural Educational Space of School and Tertiary Institution
}

\author{
Salfira I. Zamaletdinova ${ }^{1}$, Goulsia Kh. Akhmetshina ${ }^{1} \&$ Larisa R. Khrapal ${ }^{2}$ \\ ${ }^{1}$ Kazan (Volga region) Federal University, Kazan, Russia \\ ${ }^{2}$ The Institute of Pedagogic and Psychology of Professional Education of Russian Academy of Education, \\ Kazan, Russia \\ Correspondence: Salfira I. Zamaletdinova, Kazan (Volga region) Federal University, Kremlyovskaya Street 18 , \\ Kazan, 420008, Russia. E-mail: z.zamaletdinova@mail.ru
}

Received: January 19, 2014 Accepted: February 22, 2015 Online Published: March 30, 2015

doi:10.5539/res.v7n5p193 URL: http://dx.doi.org/10.5539/res.v7n5p193

\begin{abstract}
The relevance of the topic is determined by the search for the ways to improve one of the vital personality features, identity and civil identity as a driving motive in upbringing the younger generation. The aim of the paper is to reveal the content of the patriotic education model as a factor of forming civil identity of school and institute students being in multicultural education space and to define the organizing pedagogical conditions for its effective realization. The main approach to this problem research is competence approach which allows students to summon the acquired knowledge, skills, experience and ways of behavior in some definite situation or definite activity. The article may be useful for improvement the content and methods of educational work at educational institutes and the system of teachers' professional development.
\end{abstract}

Keywords: civil and patriotic education, diagnostics, patriotism, citizenship, patriot, homeland, motherland, students and youth

\section{Introduction}

\subsection{Actualizing the Problem}

Today Russia needs arrangement and creating a new ideology of youth patriotic education and the basis for this work must be forming personality civil identity based on understanding cultural diversity of the nations in Russia and their involvement in the country life. (Asmolov, 2012). The content of patriotic education must be aimed at educational process improvement at the levels of all its constituents - purpose, subject-object, content, technology, result - and be the basis for youth civil identity formation in the multicultural educational space of school and tertiary institution. (The Concept, 2008). The final result of the work should be the moral and cultural growth of today's youth, their morality, patriotic mind, civil identity, interethnic tolerance which define Russia's future (Salikhova, 2014, 2015; Chirkina, 2015).

\subsection{Explore Importance of the Problem}

Pedagogical understanding of the current situation has led to the necessity of developing the pedagogical conditions of patriotic education, able to form civil identity of modern youth. The developed conceptual model of patriotic education as a civil identity forming factor (hereinafter referred to as Conceptual Model) is presented by classified and reasoned exposition of theoretical basis for forming patriotism in students, argumentation of its initial framework, purpose, content, tasks, principles, course, forms, methods and conditions for its effective functioning.

\subsection{Specific Features of Forming Civil Identity}

The civil identity structure includes the following components:

- Cognitive (informative) — knowledge about authorities, legal basis of social organization, national symbol, socio-political events, elections, political leaders, parties and their programs, their functions and purposes;

- Emotional-evaluating (connotative) — reflexivity of knowledge and notions, having personal attitude toward socio-political events, ability to draw up clearly and reason personal position and views; 
- Axiological-respect for other people rights, tolerance, self-respect, recognition of rights for free and responsible choice for everyone, ability to determine the influence of social life on their own, readiness for accepting and analyzing social life events; accepting and respect for legal foundations of the state and society;

- Activity (behavioral) —educational institution community involvement; desire and readiness to participate in socio-political life of the country; independence in decision making, ability to resist asocial and illegal behavior and activity; responsibility for decision taking, actions and their impact (Danyluk,2009).

We have formulated the requirements for the results of civil identity developing in multicultural educational space of school and tertiary institution.

\subsection{Status of a Problem}

Civil identity (which is, from the viewpoint of a Russian researcher Semyonova, a "frame" of identity) was studied by foreign scientists Heidegger, Habermas, Hösle, Fukuyama. These scholars were interested in specific features of identity construction in multi-ethno-confessional communities, transformation of personal identification systems under the influence of sociocultural factors. Among Russian scholars, studied the problems of civil identity, we should mention Abdulatipov, Arutunan, Gudkov, Kuznetsova, Kublitskaya, Lapkin, Levada, Pantin, Semenenko, Fedotova, Yadov, who studied civil identity under the influence of globalization processes. The relevance of the problem under study, its insufficient developing made us start the research of students' civil identity formation in multicultural educational space of school.

\subsection{The Research Hypothesis}

The analysis of theoretical and practical work on the studied issue showed that the questions related to students' civil identity formation in multicultural educational space of school and tertiary institution still remain open in scientific knowledge and practical work. This permits us to propose a hypothesis for the research: Students' civil identity formation will be effective if we develop and approbate the conceptual model of patriotic education in educational institutions as a factor of students' civil identity formation at multicultural educational space of school and tertiary institution (Valeeva, Koroleva, \& Sakhapova, 2014).

\section{Materials and Methods}

\subsection{The Research Tasks}

The research tasks were: 1) to select an experimental and control group of students; 2) to develop and introduce the following programs: the program of patriotic education for students "I am a patriot"; educational program for forming tolerant mind and patriotic behavior; civil identity formation program "I am a citizen of modern Russia"; 3 ) to develop and introduce a conceptual model of patriotic education in educational institutions as a factor of students' civil identity formation in multicultural space of school and tertiary institution including the content, organizational-pedagogical conditions, methods of patriotic education (Khrapal, 2010); 4) to develop diagnostic tools to determine the level of students' civil identity (Lutovinov, 2006; Khrapal, 2010).

\subsection{Theoretical and Empirical Methods}

We used the following pedagogic research methods to solve the assigned task and to check the hypothesis: general-theoretical (analysis, synthesis, comparison and correlation, generalization, systemization, grouping and others); prognostic (pedagogic modeling); empirical (monitoring, interview, questioning, testing, study and generalization of the best educational experience); experiment; quantitative and qualitative analysis of the results pilot testing using the mathematical statistics methods.

\subsection{The Research Base}

The base for the research were secondary school No 161, gymnasium No 20 (Kazan, Tatarstan), Sokurovskaya secondary school (Laishevsky District, Tatarstan), students of Kazan (Volga region) federal university (KFU), Institute of Economics, Management and Law (IEML).

\subsection{Stages of the Research}

The research was carried out in three stages:

The first stage was conceptualization and estimation of the issue current state, studying literature on the problem under study, formulating the general principles of the research, its fundamental ideas, defining the problem, the object, the subject and the purpose of the research (Fradger, 2004; Cotesta, 2008).

The second stage included generating the strategy and the conceptual model of patriotic education as a factor of students' civil identity formation. 
The third stage was the research work completing: We organized the research results, updated the theoretic statements and formulated the research results in thesis work.

\subsection{Evaluation Criteria}

We have developed and approbated diagnostic tool for defining the level of students' civil identity maturity in the context of general secondary and higher vocational education. During developing the diagnostic complex for studying personal civil identity maturity the following was considered:

- Like any type of identity, civil identity has its structural components: cognitive (informative), emotive-evaluating (connotative), axiological, behavioral;

- On the basis of marked structural components we may suggest the availability of criteria of personal civil identity maturity: cognitive, connotative, axiological and behavioral:

- Civil identity formation develops in aspects: ethnic, all-Russia and all-cultural.

The total score can define the level of personal civil identity maturity. In accordance with the key for processing the test results we defined three levels—low, medium and high (Table 1).

Table 1. Levels and measures of civil identity maturity

\begin{tabular}{|c|c|c|}
\hline Scores & Levels & Description \\
\hline $\begin{array}{l}25-35 \\
\text { scores }\end{array}$ & High level & $\begin{array}{l}\text { - civic attitude; civic patriotism maturity; } \\
\text { - respect for the motherland history and responsibility for its status in present-day } \\
\text { world; } \\
\text { - readiness to defend your motherland and people; } \\
\text { - readiness for dialogue and networking with people of different beliefs, nations and } \\
\text { religions; } \\
\text { - active position for studying sociocultural heritage of your region and nation; }\end{array}$ \\
\hline $\begin{array}{l}14-24 \\
\text { scores }\end{array}$ & $\begin{array}{l}\text { Medium } \\
\text { level }\end{array}$ & $\begin{array}{l}\text { - unexpressed ambition for views and civic attitude, standard civic patriotism; } \\
\text { - respect for the motherland history and responsibility for its status in present-day } \\
\text { world; } \\
\text { - not strong tolerance and goodness for the nation; } \\
\text { - lack of activity to defend your motherland and people; } \\
\text { - readiness for dialogue and cooperation with people of different beliefs, nations and } \\
\text { religions; } \\
\text { - readiness for studying sociocultural heritage of your region and nation; }\end{array}$ \\
\hline $\begin{array}{c}0-13 \\
\text { scores }\end{array}$ & Low level & $\begin{array}{l}\text { - not active civic position; absence of civic patriotism; disrespect for history of the } \\
\text { motherland and irresponsibility for its life in present-day world; } \\
\text { - nontolerance and indifference for your nation; } \\
\text { - inactivity to defend your motherland and people; } \\
\text { - unreadiness for dialogue and cooperation with people of different beliefs, nations } \\
\text { and religions; } \\
\text { - low level readiness for studying sociocultural heritage of your region and nation; }\end{array}$ \\
\hline
\end{tabular}

\subsection{Experimental Procedure and Its Description}

The purpose of our experimental work was testing the influence of every organizational-pedagogical condition and their combination on the efficiency of the process of patriotic education in an educational institution as a factor for civil identity formation.

Basing on general approaches to organizing experimental work in pedagogics, we have developed a program of experimental work aimed at approbation of the developed theoretical and methodological provisions which consist of the following stages: 
1) analytical-prognostic (detailed study of the subject of the research - the process of students' civil identity formation);

2) organizational-conceptual (selecting and upgrading of the content, technological organizing the process of patriotic education; developing and introducing the diagnostic tools of the levels of civil identity maturity;

3) control-analytical (carrying out final diagnostics, experimental data analysis).

\section{Results}

\subsection{The Procedure and Results of the Experiment}

The developed conceptual model of patriotic education at educational institutions is theoretical, methodical and technological basis for providing the youth civil identity formation. The conceptual model consists of three basic moules: conative objective, content-technological and evaluative-resultative (Fig. 1).

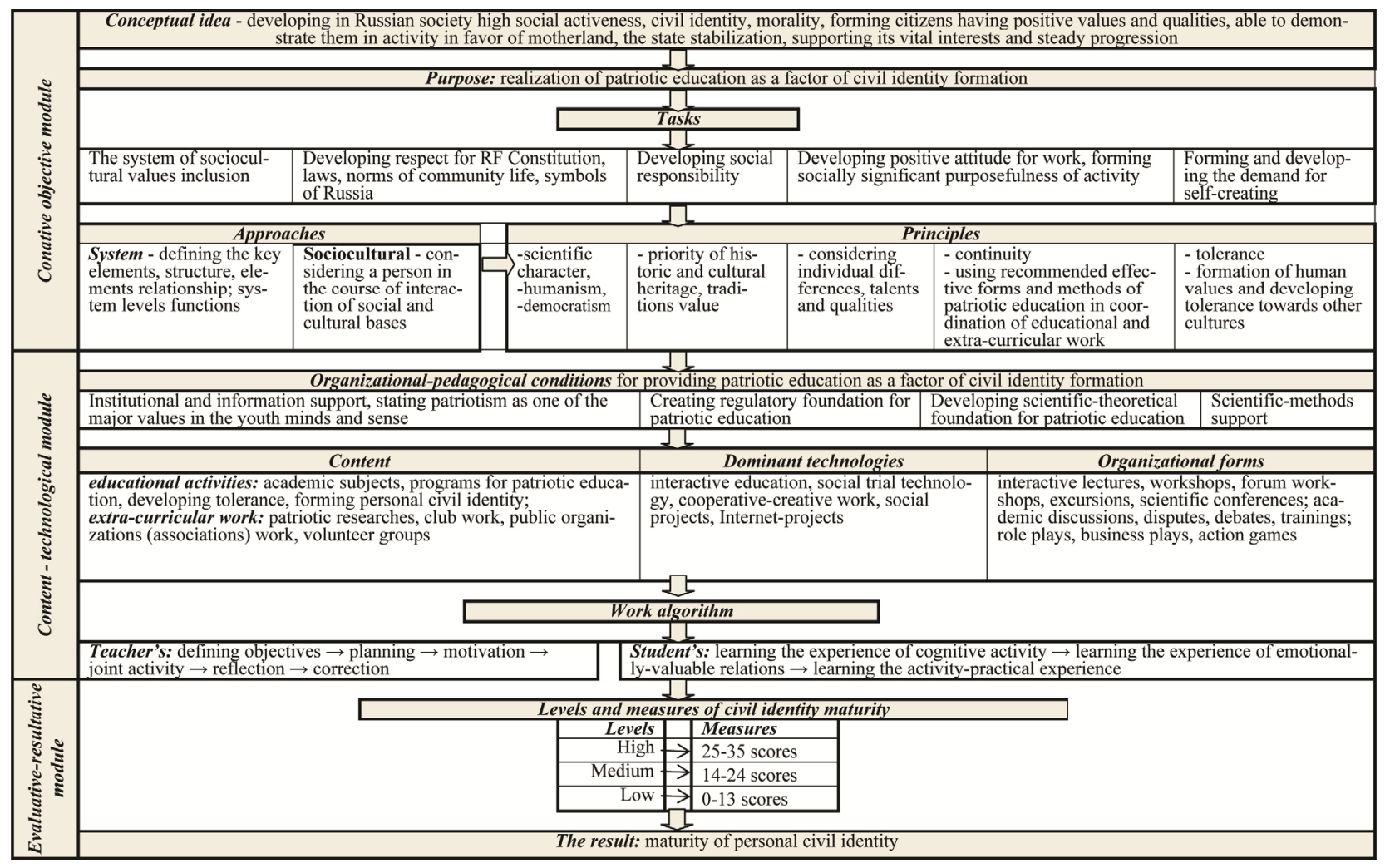

Figure 1. The conceptual model of patriotic education as a factor of students' civil identity formation

Conative objective module of the model includes major tasks, approaches and fundamental principles necessary at realization of the purposes of youth patriotic education (Jamaludinova, 2012). The system of principles of educational theory (general scientific - scientific character, humanism, democratism; axiological-historic and cultural heritage, values and traditions priority; psychological-pedagogical-considering individual differences, talents and qualities; continuity - using recommended effective forms and methods of patriotic education in coordination of educational and extra-curricular work; tolerance-formation of human values and developing tolerance towards other cultures) carries out the conceptual function of education, hence defines the approaches to selecting the contents, forms and techniques of education (Mazhitova, 2010).

Content-technological module includes organizational-pedagogical conditions for providing patriotic education as a factor of civil identity formation and inter-ethnic tolerance, content, dominant technologies and organizational forms of patriotic education, algorithm of teacher's and students' work (Loginova, 2010).

The criteria and measures of civil identity maturity and inter-ethnic tolerance are introduced in evaluative-resultative module.

Effective solution of the task of patriotic education as a factor of students civil identity formation is impossible 
without verifying the developed organizational-pedagogical conditions.

Carrying out the first organizational-pedagogical condition-institutional and informational support, stating patriotism as one of the major values in the youth minds and sense, we have issued and solved a range of tasks: certain filling the patriotic idea in close connection with the state, society and person interests; task-oriented creative use of positive potential of patriotism ideas in the process of pedagogic work (Khrapal, 20100. We have developed and introduced: the program of patriotic education "I am a patriot"; educational program of forming tolerant mind and patriotic behavior (Ochirova, 2009).

In the course of checking the efficiency of the second organizational-pedagogical condition-creating regulatory foundation for patriotic education - we have issued and solved a range of tasks: to define the role, place, social and legal status, challenges, functions of certain schools and tertiary institutions as components of integrated system of patriotic education considering their specific features. The methodological foundation for developing the technologies of students' civil identity formation were the following acts: "National strategy of acting for the benefits of children for the years 2012-2017"; "Concept of moral development and personality education for Russia citizens"; "Fundamentals of basic education content"; "Federal state educational standard of secondary education" etc.

Checking the efficiency of the third organizational-pedagogical condition-developing scientific-theoretical foundation for patriotic education supposed the following tasks realization: updating the content of disciplines by including cultural-historical, military history, moral, ideological, social-psychological and other aspects; creating innovative supplementary courses for youth patriotic education on the basis of the technologies use experience: person-oriented education; the cooperative learning technologies; group technologies; technologies of collective interaction; technologies of research (problem) education and others (Polat, 2000).

The fourth organizational-pedagogical condition realization consisted in scientific and methodological support for patriotic education at educational organization-developing and introducing the program of teachers professional development "Developing personal civil identity in the context of sociocultural modernization of education"; the program of youth civil identity formation "I am a citizen of modern Russia", the use of modern pedagogical technologies in teacher's work for patriotic education-interactive teaching forms and methods: interactive lectures, workshops, forum workshops, excursions, scientific conferences; academic discussions, disputes, debates, trainings; role plays, business plays, action games, social trial technology, cooperative-creative work, social projects, Internet-projects (Rudenko, 2005).

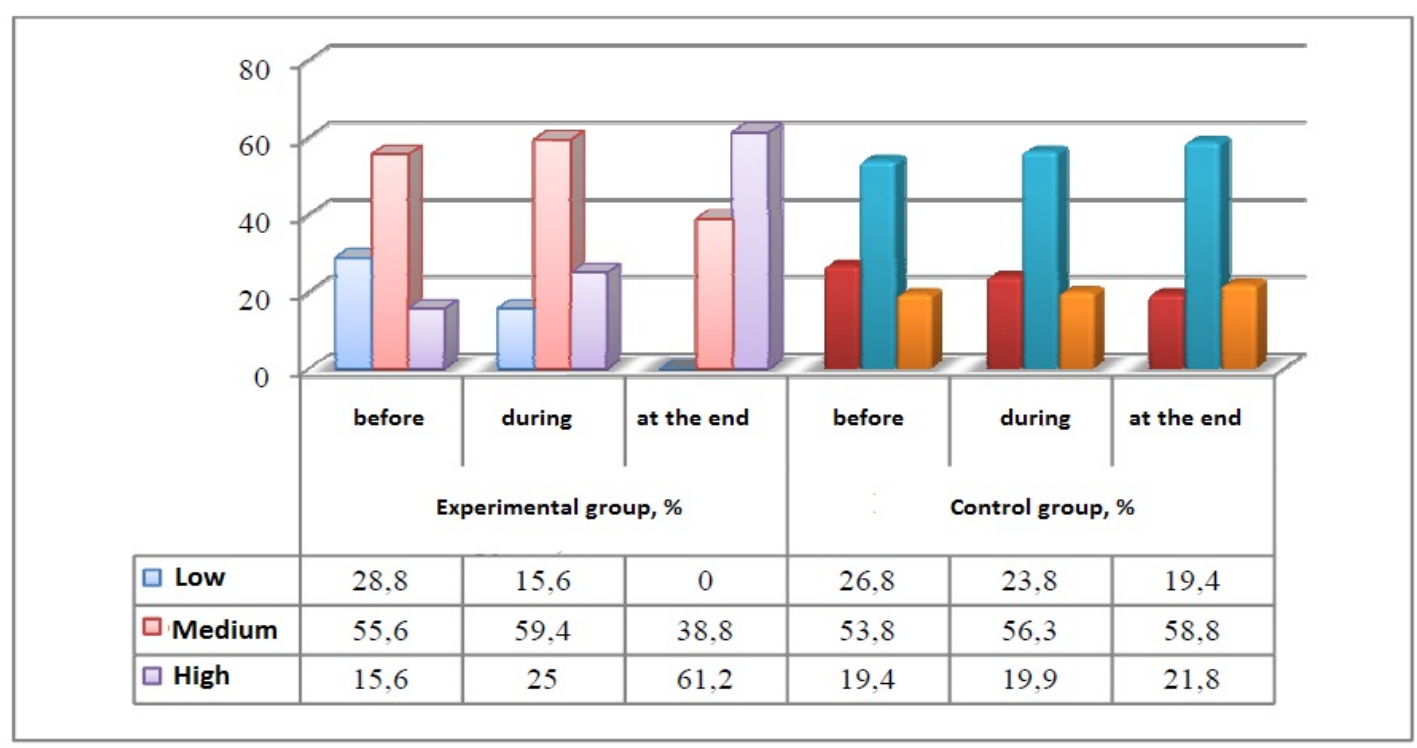

Figure 2. The levels of personal civil identity maturity at the beginning and end of pedagogical experiment

The experiment results prove that the process of students' civil identity formation is effective in the context of realization of the mentioned complex of pedagogical conditions. The selected technologies of the youth patriotic 
education allowed organizing formation of civil identity by means of appropriate methods, forms and educational means.

\section{Discussion}

The problems of civil identity formation were studied by many Russian scholars. The substantial contribution was made by a native scientist Drobizheva (2006). Her research works generalized the results of the projects which analyzed Russia's identity in its regional diversity, the issues devoted to identity formation in Russia were studied and the difference in terms "state identity" and "civil identity" was reasoned. Different appearance of forming civil identity as state identity; the studying of the youth socialization processes, its identity formation; civil and legal socialization; social and civic engagement, Russian youth civil and legal values and orientation were deeply studied by native scholars.

Our research uses new organizational-pedagogical conditions for the student's patriotic education as the main factor of civil identity formation. We have developed the conceptual model of patriotic education in educational institutions as a factor of students' civil identity formation in multicultural educational space of school and tertiary institution.

\section{Conclusion}

The suggested conceptual model of patriotic education as a factor of students civil identity formation in multicultural educational space of school and tertiary institution, including organizational-pedagogical conditions, the variety of methods, principles, tasks and technologies used in the process of education, allows modern education to update, emphasizes the necessity in developing conceptual foundations of Russia's national security and fundamental changes in the system of patriotic education.

The developed diagnostic tool for defining the level of students' civil identity maturity, including the criteria and levels, allows defining the statements and controllers of a person becoming cultural, a citizen and a patriot, a good representative of the 21 st century generation.

\section{Acknowledgments}

The work is performed according to the Russian Government Program of Competitive Growth of Kazan Federal University

\section{References}

Asmolov, A. G. (2009). The strategy and methodology of social and cultural modernization of education. Retrieved from http://gigabaza.ru/doc/97307.html

Chirkina, S. E. (2015). Adults' meaning-making during vocational training. Review of European Studies, 7(4), 128-132. http://dx.doi.org/10.5539/res.v7n4p128

Cotesta, V. (2008). From national-state to global society: the changing of contemporary sociology. International Review of Sociology, 1, 26. http://dx.doi.org/10.1080/03906700701823621

Danyluk, A. J., Kondakov, A. M., \& Tishkov, V. A. (2009). The concept of spiritual and moral development and education of a citizen of Russia (p. 24). Moscow, Russia.

Drobizheva, L. M. (2006). Social problems of interethnic relations in post-Soviet Russia. Civil, ethnic and religious identity in modern Russia.

Fradger, R., \& Fademen, D. (2004). Theory of personality and personal growth-Prime-Eurosac (p. 608). St. Petersburg, Russia.

Jamaludinova, Z. (2012). The Formation of Russian identity as a factor of Patriotic education of younger students (Thesis of candidate of pedagogical Sciences). Makhachkala.

Khrapal, L. R. (2010). Diagnostic tools to identify the level of modernized ethno-cultural identity of the future specialist. Higher education today, 9, 88-90.

Khrapal, L. R. (2010). Modernization of environmental education at the University in the context of the Russian socio-cultural dynamics: Monograph (p. 388). Kazan, Russia.

Khrapal, L. R. (2010). The resolution of regional, national, and ethnic and religious problems of the society in the conditions of modernization of the environmental education policy in higher education. Higher education today, 6, 88-91.

Loginova, A. A. (2010). The formation of civil identity pupils by means of Internet projects (Thesis of candidate of pedagogical Sciences). Samara. 
Lutovinov, C. I. (2006). The criteria and basis for assessment of the results of the work on Patriotic education (p. 69). Moscow, Russia.

Mazhitova, A. R. (2010). The problem of personal identity in the context of globalization. Fates of national cultures in terms of globalization, 1, 84-89.

Ochirova, N. P. (2009). The formation of spiritual and moral values of students on the basis of the dialogue of cultures (Thesis of candidate of pedagogical Sciences). Elista.

Polat, E. C. (2000). Pedagogical technologies of the XXI century. Contemporary problems of education, 172.

Rudenko, C. I. (2005). The formation of patriotism as values in students (p. 154). Tyumen, Russia.

Salikhova, N. R. (2014). Correlation of meaningfulness of life to psychological time in Personality. Asian Social Science, 10(19), 291-295. http://dx.doi.org/10.5539/ass.v10n19p291

Salikhova, N. R. (2015). The comparison of substantial and dynamic parameters personal value-meaning systems of American and Russian university students. Review of European Studies, 7(4), 117-123. http://dx.doi.org/10.5539/res.v7n4p117

Valeeva, R. A., Koroleva, N. E., \& Sakhapova, F. K. (2014). Civic education of the technical university students in foreign language classes. Review of European Studies, 7(1), 176-181. http://dx.doi.org/10.5539/res.v7n1p176

\section{Copyrights}

Copyright for this article is retained by the author(s), with first publication rights granted to the journal. This is an open-access article distributed under the terms and conditions of the Creative Commons Attribution license (http://creativecommons.org/licenses/by/3.0/). 